\title{
The database of the Danish Renal Cancer Group
}

This article was published in the following Dove Press journal:

Clinical Epidemiology

25 October 2016

Number of times this article has been viewed

\author{
Astrid Christine Petersen' \\ Mette Søgaard ${ }^{2}$ \\ Frank Mehnert ${ }^{2}$ \\ Erik Højkjær Larsen ${ }^{3}$ \\ Frede Donskov ${ }^{4}$ \\ Nessn H Azawi ${ }^{5}$ \\ Bjarne Kromann-Andersen ${ }^{6}$ \\ 'Department of Pathology, \\ Aalborg University Hospital, \\ Aalborg, ${ }^{2}$ Department of Clinical \\ Epidemiology, Aarhus University \\ Hospital, Aarhus, ${ }^{3}$ Department of \\ Urology, Odense University Hospital, \\ Odense, ${ }^{4}$ Department of Oncology, \\ Aarhus University Hospital, Aarhus, \\ ${ }^{5}$ Department of Urology, Zealand \\ University Hospital, Roskilde, \\ ${ }^{6}$ Department of Urology, Herlev \\ and Gentofte Hospital, Copenhagen, \\ Denmark
}

Aim of the database: The main purpose of the database of the Danish Renal Cancer Group (DaRenCaData) is to improve the quality of renal cancer treatment in Denmark and secondarily to conduct observational research.

Study population: DaRenCaData includes all Danish patients with a first-time diagnosis of renal cancer in the Danish National Pathology Registry since August 1, 2010.

Main variables: DaRenCaData holds data on demographic characteristics, treatments, and pathology collected through linkage to central registries and online registration of a few clinical key variables. Eight quality indicators have been selected for monitoring treatment quality and outcome after renal cancer.

Descriptive data: The incidence of renal cancer in Denmark has increased from 12.7 per 100,000 population-years in 2010-2011 to 15.9 per 100,000 population-years in 2014-2015. A total of 3,977 Danish patients with renal cancer have been enrolled in the database in the period August 1, 2010-July 31, 2015. The completeness of data registration has increased substantially since the first years of the database. A tendency toward smaller and less advanced tumors, less invasive surgery, and a shorter hospital stay was observed, while the postoperative morbidity and mortality remained stable. Concurrently, the 1-year survival has improved and was $84.1 \%$ in $2014-2015$.

Conclusion: DaRenCaData provides valuable information on quality of and outcome after renal cancer treatment. Efforts to improve collection and registration of data are ongoing.

Keywords: kidney cancer, database, clinical quality, indicators, incidence, survival, observational research

\section{Background}

Renal cancer accounts for 3\%-4\% of new cancer cases in adults. ${ }^{1-3}$ Data from the Nordic cancer registry NORDCAN show that renal cancer in Denmark in the years 2009-2013 comprised $2.5 \%$ of all new male and $1.4 \%$ of all new female cancer cases. ${ }^{3}$ Survival after renal cancer has been lower in Denmark compared to the other Nordic countries for decades. ${ }^{3,4}$

The multidisciplinary Danish Renal Cancer Group (DaRenCa) was established in 2006 following a national plan to improve survival of cancer for all Danish patients. ${ }^{5}$ DaRenCa is a group of academic experts representing urology, oncology, pathology, radiology, nuclear medicine, and epidemiology dealing with cancer originating from the renal parenchyma. The aim of DaRenCa is to improve the renal cancer survival in Denmark, and the group is responsible for developing national guidelines for diagnosis and treatment of renal cancer. The nationwide database of the DaRenCa
Correspondence: Astrid Christine Petersen Department of Pathology, Aalborg University Hospital, Ladegaardsgade 3 , 9000 Aalborg, Denmark

Tel +459766 5278

Fax +45 97665320

Email acp@rn.dk
Clinical Epidemiology 2016:8 725-729 (Thematic series on clinical quality databases in Denmark) $\quad \mathbf{7 2 5}$

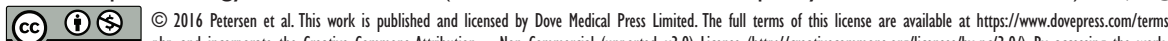
cc. ${ }_{\mathrm{BY}} \mathrm{NC}$ php and incorporate the Creative Commons Attribution - Non Commercial (unported, v3.0) License (http://creativecommons.org/licenses/by-nc/3.0/). By accessing the work you hereby accept the Terms. Non-commercial uses of the work are permitted without any further permission from Dove Medical Press Limited, provided the work is properly attributed. For permission for commercial use of this work, please see paragraphs 4.2 and 5 of our Terms (https://www.dovepress.com/terms.php).
Dovepress

http://dx.doi.org/10.2147/CLEP.SI06042 
(DaRenCaData) was established in 2010 as one of the other tasks of the group.

\section{Aim of the database}

The main purpose of the database is to improve the clinical quality of renal cancer treatment in Denmark by monitoring selected processes and outcome after renal cancer treatment and secondarily to provide an important data source for observational research.

\section{Study population}

DaRenCaData includes all patients with a first-time diagnosis of renal cancer in Denmark since August 1, 2010. The patients are identified by the first-time registration of a diagnosis of renal cancer in the Danish National Pathology Registry to secure verification by histology or cytology. ${ }^{6}$ Through the Danish National Patient Registry, the database additionally identifies all surgical treatment procedures performed on patients with renal cancer. ${ }^{7}$

\section{Main variables}

The variables in the database are obtained from two main sources: through data linkage from central national registries and through data registered online in a web-based form by the treating clinicians. This online registration form is part of a common platform for the five urooncological databases in Denmark. ${ }^{8}$

Information on sex, age, and vital status is retrieved from the Danish National Civil Registry. ${ }^{9}$

Data on specific surgical and oncological treatment as well as comorbidity are retrieved from the National Patient Registry. ${ }^{7}$ These data are part of the routine registration done in connection with procedures performed during hospitalization and outpatient treatment at hospitals. The surgical procedures are registered as radical or partial nephrectomies or ablative procedures (cryotherapy and radio frequency ablation), and whether the procedures are performed laparoscopically or open. Variables describing the surgical quality include information on the length of hospital stay, 30-day postoperative mortality, and 30-day postoperative morbidity. Information on specific oncological treatment modalities is also retrieved.

Systematized Nomenclature of Medicine codes for the histological subtype of cancer, Fuhrman grade, Leibovich score, pT-stage, and type of specimen are drawn from the Danish National Pathology Registry. ${ }^{6}$

Additional data from the web-based form include: civil registration number as patient identifier, date of diagnosis, main debut symptoms (incidentally found tumor, hematuria, nonspecific symptoms), and results of blood tests performed at the time of diagnosis (hemoglobin, C-reactive protein, ionized calcium, lactate dehydrogenase, serum sodium, neutrophils). The database is not collecting data on lifestyle factors. In case of locoregional or metastatic recurrent disease, a special recurrence form is used.

Eight quality indicators with recommended standards based on experience and available literature have been selected for monitoring the clinical quality of renal cancer treatment in Denmark. These indicators collected once a year include description of the treatment of renal cancer (process indicators) as well as description of outcome (result indicators).

\section{Data quality}

As most data come from preexisting registries and only a few data are registered manually in the web-based forms, it should be possible to achieve a high completeness of data, obviously depending on the quality of these data.

All urological, surgical, oncological, and other departments diagnosing and treating patients with renal cancer register online in the web-based form at the time of diagnosis. This form was filled in for $89.0 \%$ of all new renal cancer cases during the last study period August 1, 2014-July 31, 2015 , with a variation between departments treating more than ten patients between $37.5 \%$ and $98.6 \%$. This registration has improved over the years: $65.4 \%$ in $2010-2011,69.3 \%$ in 2011-2012, 82.3\% in 2012-2013, and 84.4\% in 2013-2014. Ten urological departments diagnosed more than ten new patients with kidney cancer in 2014-2015. Four of these had a high and stable registration rate during all 5 years with a mean between $88.0 \%$ and $95.9 \%$. Five improved their registration substantially, one from $14.5 \%$ to $87.7 \%$ and another from $52.9 \%$ to $95.0 \%$. Only one department showed a decrease in registration from $76.2 \%$ to $37.5 \% .^{10}$

As DaRenCaData is a newly established database with only 5 years of data collection to date, results and data from the initial years should be interpreted with caution. During the recent years, the algorithms for identification of patients with incident renal cancer in the pathology registry have been optimized. As a result, the data completeness and validity have improved over time. In particular, the algorithms have been redefined, and data from five larger hospitals diagnosing and treating patients with renal cancer have undergone a detailed validation of data concerning the surgical procedures and pathological data. This validation revealed that the main reason for incomplete data was incorrect or incomplete registration of some of the clinical and pathological data. Validation of data on oncological treatment is currently 
Table I Characteristics of the patient population in DaRenCaData

\begin{tabular}{|c|c|c|c|c|c|}
\hline \multirow[t]{2}{*}{ Characteristics } & \multicolumn{5}{|c|}{ Year of diagnosis (August I-July $3 \mathrm{I}$ ) } \\
\hline & $2010-2011$ & $2011-2012$ & $2012-2013$ & $2013-2014$ & 2014-2015 \\
\hline New cases & 705 & 724 & 769 & 880 & 899 \\
\hline New cases per 100,000 citizens, $n$ & 12.7 & 13.0 & 13.7 & 15.6 & 15.9 \\
\hline Women, n (\%) & $230(32.6)$ & $242(33.4)$ & $267(34.7)$ & $305(34.7)$ & $313(34.8)$ \\
\hline Men, n (\%) & $475(67.4)$ & $482(66.6)$ & $502(65.3)$ & $575(65.3)$ & $586(65.2)$ \\
\hline \multicolumn{6}{|l|}{ Age at diagnosis (years) } \\
\hline Median & 65 & 64 & 66 & 67 & 67 \\
\hline 25 th percentile & 57 & 56 & 58 & 57 & 57 \\
\hline 75th percentile & 72 & 71 & 73 & 73 & 74 \\
\hline \multicolumn{6}{|l|}{ Comorbidity at diagnosis ${ }^{a}$} \\
\hline Score 0, n (\%) & $354(50.2)$ & $394(54.4)$ & $412(53.6)$ & $463(52.6)$ & $487(54.2)$ \\
\hline Score I-2, n (\%) & $242(34.3)$ & $218(30.1)$ & $242(31.5)$ & $278(31.6)$ & $277(30.8)$ \\
\hline \multirow[t]{3}{*}{ Score 3+, n (\%) } & $109(15.5)$ & $112(15.5)$ & II5 (I5.0) & $139(\mid 5.8)$ & I $35(\mid 5.0)$ \\
\hline & \multicolumn{5}{|c|}{ Year of surgery (August I-July 3I) } \\
\hline & $2010-2011$ & $2011-2012$ & $2012-2013$ & $2013-2014$ & 2014-2015 \\
\hline Surgical procedures, $\mathrm{n}$ & 591 & 644 & 656 & 749 & 807 \\
\hline Median age at surgery & 64 & 64 & 65 & 65 & 66 \\
\hline
\end{tabular}

Notes: a'Given as Charlson comorbidity index score. ${ }^{14}$ Data from DaRenCa, a subgroup of Dansk Urologisk Cancer Gruppe. ${ }^{11}$

Abbreviation: DaRenCaData, database of the Danish Renal Cancer Group.

ongoing. Further validation studies will ensure an even higher completeness and validity of all data in DaRenCaData in the future.

\section{Main results}

During the period August 1, 2010-July 31, 2015, 3,977 patients with renal cancer have been enrolled in the database. ${ }^{11}$ Over this period, incidence has increased in total number of new cases and number of new cases per 100,000 citizens (Table 1). ${ }^{12}$

The eight quality indicators as well as results from 2010 to 2015 are summarized in Table 2..$^{10,11}$

There has been a tendency toward use of more minimal invasive procedures with lesser surgical traumas. The proportion of radical nephrectomies performed laparoscopically has increased from $60.0 \%$ in $2010-2011$ to $66.4 \%$ in

Table 2 Quality indicators and indicator results in DaRenCaData

\begin{tabular}{|c|c|c|c|c|c|c|c|c|}
\hline \multicolumn{2}{|c|}{ Indicator } & \multirow[t]{3}{*}{ Standard (\%) } & \multirow[t]{3}{*}{ Type } & \multicolumn{5}{|l|}{ Result (\%) } \\
\hline & & & & \multicolumn{5}{|c|}{ Year of diagnosis (August I-July 3I) } \\
\hline & & & & $2010-201 I^{10}$ & $2011-2012^{11}$ & $2012-2013^{\prime \prime}$ & $2013-2014^{\prime 1}$ & $2014-2015^{11}$ \\
\hline la & $\begin{array}{l}\text { Proportion of localized disease } \\
(\mathrm{TI}-2, \mathrm{~N} 0 / \mathrm{x}, \mathrm{MO} / \mathrm{x}) \text { at diagnosis }\end{array}$ & $\geq 65$ & Process & 51.2 & 50.0 & 52.5 & 54.3 & 54.8 \\
\hline $\mathrm{Ib}$ & $\begin{array}{l}\text { Proportion of localized disease } \\
(\mathrm{Tla}, \mathrm{N} 0 / \mathrm{x}, \mathrm{MO} / \mathrm{x}) \text { at diagnosis }\end{array}$ & Not yet defined & Process & 20.0 & 21.0 & 23.7 & 29.8 & 27.6 \\
\hline $2 \mathrm{a}$ & $\begin{array}{l}\text { Proportion of radical nephrectomies } \\
\text { for local disease }(\mathrm{TI}-2) \text { performed } \\
\text { laparoscopically }\end{array}$ & $\geq 85$ & Process & 65.3 & 75.9 & 74.4 & 76.0 & 76.4 \\
\hline $2 b$ & $\begin{array}{l}\text { Proportion of radical nephrectomies } \\
\text { performed laparoscopically }\end{array}$ & $\geq 65$ & Process & 60.0 & 62.2 & 64.9 & 68.2 & 66.4 \\
\hline 3 & 30-day morbidity & $\leq 5$ & Result & 4.3 & 4.3 & 3.4 & 4.2 & 4.4 \\
\hline 4 & Recurrence $^{a}$ within 3 years & $\leq 25$ & Result & 28.9 & 29.2 & & & \\
\hline 5 & 30-day mortality & $\leq 0.5$ & Result & 0.7 & 1.6 & 0.5 & 0.7 & 0.4 \\
\hline $6 a$ & I-year observed survival & $\geq 80$ & Result & 81.3 & 81.9 & 83.4 & 84.1 & \\
\hline $6 b$ & 3-year observed survival & Not yet defined & Result & 68.2 & 69.9 & & & \\
\hline 7 & $\begin{array}{l}\text { Hospital stay } \leq 3 \text { days after an } \\
\text { endoscopic or ablative procedure }\end{array}$ & $\geq 85$ & Result & 68.1 & 70.9 & 75.2 & 75.3 & 80.1 \\
\hline 8 & $\begin{array}{l}\text { Proportion of } \mathrm{Tl} \text { a tumor treated by } \\
\text { radical nephrectomy }\end{array}$ & $\leq 10$ & Result & 46.7 & 35.0 & 25.1 & 26.8 & 17.4 \\
\hline
\end{tabular}

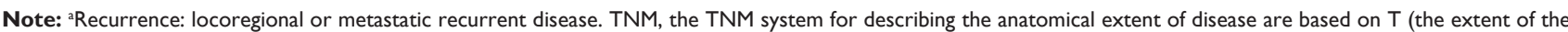
primary tumour); $\mathrm{N}$, the absence or presence of regional lymph node metastasis; $\mathrm{M}$, the absence or presence of distant metastasis.

Abbreviation: DaRenCaData, database of the Danish Renal Cancer Group. 
2014-2015. ${ }^{11}$ The proportion of nephron-preserving procedures (partial nephrectomy and ablation) increased from $22.9 \%$ in $2010-2011$ to $43.5 \%$ in $2014-2015$, and the proportion of patients with T1a $(\leq 4 \mathrm{~cm})$ cancers who underwent a radical nephrectomy decreased from $46.7 \%$ in $2010-2011$ to $17.4 \%$ in $2014-2015 .{ }^{11}$ The proportion of patients who were hospitalized for 3 days or less after an endoscopic or ablative procedure increased from $68.1 \%$ to $80.1 \%$ during the last 5 years, while the postoperative morbidity and mortality was stable during the last 5 years. ${ }^{11}$

Tumor size at diagnosis tends to be smaller and less advanced in the most recent years. The number of radical and partial nephrectomies with pT1a tumors increased from $17.6 \%$ in $2011-2012$ to $29.8 \%$ in $2014-2015$, while the number of patients with pT3-4 tumors decreased from $45.0 \%$ in $2011-2012$ to $29.8 \%$ in $2014-2015$. $^{11}$

Information on the specific histological subtype, which is an important prognostic factor and used for determining later treatment of metastatic disease, was recorded for 53\% of the newly diagnosed patients in 2010-2011, 74.5\% in 2011-2012, 87.5\% in 2012-2013, 83.8\% in 2013-2014, and $85.9 \%$ in $2014-2015 .^{11}$

The 1-year observed survival after the diagnosis of renal cancer increased from $81.3 \%$ for patients diagnosed in 2010-2011 to $84.1 \%$ in patients diagnosed in 2014-2015. ${ }^{11}$ The 3-year observed survival was $68.2 \%$ for patients diagnosed in 2010-2011, and 69.9\% for patients diagnosed in 2011-2012. ${ }^{11}$

\section{Follow-up}

All patients enrolled in the database are followed until death or emigration with collection of data comprising surgical and medical oncological treatment as well as data on the date and type of recurrence.

Data suggested to be included during follow-up in the future are, among others, the development of a new primary renal cancer in the residual and/or contralateral kidney and development of renal insufficiency after renal surgery.

\section{Research}

No research projects have evolved until now, but in the coming years, the database will be provide the basis for and conduct several observational studies of Danish patients with renal cancer.

\section{Administrative issues and funding}

DaRenCaData is funded by the Danish Regions by the Danish Clinical Registries as one of more than 60 national clinical quality databases in Denmark. ${ }^{13}$ Epidemiological, statistical, and technical support is provided by two regional registry support centers in Denmark (The Registry Support Center of Epidemiology and Biostatistics [North] and The Registry Support Center of Clinical Quality and Health Informatics [West]). The database is headed by a steering group representing the specialties in DaRenCa supplied by biostatistics and quality improvement. An annual report is published each year covering the period from August 1of the first year to July 31 of the next year. ${ }^{11}$ The publication follows a national audit by the steering group of national-, regional-, and institutional-based results. After publication, the regions and departments perform a local audit of the results for their own organization.

\section{Conclusion}

DaRenCaData was established in 2010 to provide valid information on renal cancer statistics.

Data from the first 5 years of the database suggest an improvement of survival, a tendency toward smaller and less advanced tumors at the time of diagnosis, and an increased use of less invasive surgery.

It is important to note that the database is relatively young, and the data from the first years should be interpreted with caution. Nevertheless, the completeness of the online registration has improved substantially during these first 5 years. Effort to improve data completeness and validity is ongoing.

\section{Acknowledgments}

All former and current members of DaRenCa (Astrid Petersen, Bjarne Kromann-Andersen, Claus V Jensen, Erik H Larsen, Frede Donskov, Gregers G Hermann, Helle W Hendel, Lars Lund, Lars Ulrich Hansen, Mette Nørgaard, Nessn Azawi, Niels Viggo Jensen, Niels Marcussen, Poul G Geertsen, Torben Dørflinger and Ulla Møldrup) have contributed to the development of the database. This paper was funded by the Program for Clinical Research Infrastructure (PROCRIN) established by the Lundbeck Foundation and the Novo Nordisk Foundation and administered by the Danish Regions.

\section{Disclosure}

The authors report no conflicts of interest in this work.

\section{References}

1. Siegel RL, Miller DM, Jemal A. Cancer Statistics, 2016. CA Cancer J Clin. 2016;66(1):7-30.

2. Thorstenson A, Bergman B, Scherman-Plogell A-H, et al. Tumour characteristics and surgical treatment of renal cell carcinoma in Sweden 2005-2010: a population-based study from the National Swedish Kidney Cancer Register. Scan J Urol. 2014;48(3):231-238. 
3. Engholm G, Ferlay J, Christensen N, et al. NORDCAN: Cancer Incidence, Mortality, Prevalence and Survival in the Nordic Countries, Version 7.2 (16.12.15). Association of Nordic Cancer Registries. [homepage on the Internet]. Nordic Cancer Data. Available from: http://www.ancr.nu. Accessed June 19, 2016.

4. Engholm G, Hakulinen T, Gislum M, et al. Trends in the survival of patients diagnosed with kidney or urinary bladder cancer in the Nordic countries 1964-2003 followed up to the end of 2006. Acta Oncol. 2010;49(5):655-664.

5. The Danish National Board of Health [homepage on the Internet]. Healt Recommendations, Health Data, Cancer Treatment and Planning. Available from: https://sundhedsstyrelsen.dk/da/udgivelser/2005/ kraeftplan-ii. Accessed June 19, 2016.

6. Erichsen R, Lash TL, Hamilton-Dutoit SJ, Bjerregaard B, Vyberg M, Pedersen L. Existing data sources for clinical epidemiology: the Danish National Pathology Registry and Data Bank. Clin Epidemiol. 2010;9(2):51-56.

7. Andersen TF, Madsen M, Jorgensen J, Mellemkjaer L, Olsen JH. The Danish National Hospital Register. A valuable source of data for modern health sciences. Dan Med Bull. 1999;46(3):263-268.
8. Den Uroonkologiske Fællesdatabase [homepage on the Internet] Databases of Urological Cancer. [Updated June 1, 2015]. Available from: http://ducg.dk/database. Accessed June 19, 2016.

9. Pedersen CB, Gotzsche H, Moller JO, Mortensen PB. The Danish Civil Registration System. A cohort of eight million persons. Dan Med Bull. 2006;53(4):441-449.

10. Mehnert F. Personal communication. March 2, 2016.

11. Dansk Urologisk Cancer Gruppe [homepage on the Internet]. Guidelines and Data on Urological Cancer. [Updated February 8, 2016]. Available from: http://ducg.dk/nyrecancer/aarsrapporter. Accessed June 19, 2016.

12. Danmarks Statistik. [homepage on the Internet]. Danish Demografic Data. [Updated June 17, 2016]. Available from: http://www.statistikbanken.dk/statbank5a/default.asp?w=1366. Accessed June 19, 2016.

13. Regionernes kliniske kvalitetsudviklingsprogram [homepage on the Internet]. Clinical Quality Improvement. Danske Regioner. [Updated March 7, 2016]. Available from: http://www.rkkp.dk. Accessed June $19,2016$.

14. Charlson ME, Pompei P, Ales KL, MacKenzie CR. A new method of classifying prognostic comorbidity in longitudinal studies: development and validation. J Chronic Dis. 1987;40(5):373-383.
Clinical Epidemiology

\section{Publish your work in this journal}

Clinical Epidemiology is an international, peer-reviewed, open access, online journal focusing on disease and drug epidemiology, identification of risk factors and screening procedures to develop optimal preventative initiatives and programs. Specific topics include: diagnosis, prognosis, treatment, screening, prevention, risk factor modification,

Submit your manuscript here: http://www.dovepress.com/clinical-epidemiology-journa

\section{Dovepress}

systematic reviews, risk \& safety of medical interventions, epidemiology \& biostatistical methods, and evaluation of guidelines, translational medicine, health policies \& economic evaluations. The manuscript management system is completely online and includes a very quick and fair peer-review system, which is all easy to use. 